Goran Obradović, LL.D. ${ }^{*}$

Associate Professor,

Faculty of Law, University of Niš
ОРИГИНАЛАН НАУЧНИ ЧЛАНАК

doi:10.5937/zrpfni16720930

UDK: 331.101.264.2"18/19“

Рад примљен: 12.04.2016.

Рад прихваћен: 11.05.2016.

\title{
POPE LEO XIII'S RERUM NOVARUM ${ }^{* *}$
}

\begin{abstract}
The late 19th and early 20th centuries were marked by significant advances in production, which were in large part a consequence of numerous discoveries which were being made with increasing rapidity. The condition of workers had not followed those advances, who were instead their victims. Ever increasing societal wealth was accumulating in the hands of a small number of people while the vast majority of workers existed on the very edge of physical survival. Ever more frequent and emphatic dissatisfaction impelled states and prominent social functionaries to take a stance on the condition of workers and take measures to improve it. Aware of the extremely disadvantageous condition of the workers, but also of the danger posed by socialism and communism, Pope Leo XIII acted accordingly, particularly through his encyclical Rerum novarum. This work takes into consideration the condition of workers at the time of the encyclical's issuing, analyses its content, and in one section examines the significance of the encyclical and its influence on the further development of workers' rights.
\end{abstract}

Key words: Rerum novarum, labour, workers, strike.

\section{Introduction}

For labour law to be created it was, before all else, necessary to create such economic development and changes in economic life that would lead to greater and continued demand for a labour force and the creation of wage labourers. The essential characteristic of wage labourers is that they are individuals free in a

\footnotetext{
*obrad@prafak.ni.ac.rs

** This paper is a result of research conducted within the project "Protection of Human and Minority Rights in the European Legal Space" (No. 179046), which has been funded by the Ministry of Education, Science and Technological Development of the Republic of Serbia within the 2011-2014 project period.
} 
double sense: legally free to enter legal relations with other persons and "free of means of production", i.e. they possess nothing besides their labour power, so that they are forced to hire out their labour power to others (Tintić, 1969:117). The then reigning liberalism, starting from the principle of primary and natural liberty of man, based itself on the understanding that the liberty of man can be chipped away with their personal consent only, i.e. contractually. However, that formal liberty and equality gave the employers full reign (Bajič, 1937:10). Without state intervention in the domain of labour, i.e. without the guarantee of minimal rights on the basis of wage labour, the worker was compelled to accept labour conditions offered by the employer, without any recourse to affect them. ${ }^{1}$ Besides, even the contractually agreed upon rights were frequently not respected and the fear of losing their jobs forced many into labour unbefitting to man.

State intervention, regardless of the need for it, was employed to a very small degree. According to the liberal conception of spontaneous order, every meddling of state, particularly in regard to recognizing the social rights of citizens unprovided for by the state, would necessarily cause irreparable material collapse of the social whole (the nation) and that would impede its progress (Stupar, 1963: 67). Every social act of the state was completely repudiated, while some proponents of the theory have repudiated even private acts of providing protection to unprovided for persons (Stupar, 1963: 67). Considering that unhealthy and difficult working conditions were, primarily, a consequence of the freedom of contract, workers soon thereafter became a social question which would lead to the appearance of workers' movements (Ravnić, 2004:339-340).

\section{The condition of workers at the end of the XIX and the beginning of $X X$ centuries}

In the factories of that time it was entirely customary to have unlimited working hours, to have women and children working in mines, to not pay wages in legal tender, and to conduct labour in unhygienic conditions (Bajič, 1937:10). Labour relations were considered a part of economic relations and completely subject to the laws of the market, labour itself was considered a commodity. Economic learning within the framework of liberal philosophy is called economism, considering it was constructed by the English classical school of economics. It led to an enormous growth of industrial production and development of trade, to the opening of a great number of new workplaces, but also to unheard of exploitation of workers (Ravnić, 2004:335-336). In other words, new workplaces, the growth of industrial production and gross domestic product by themselves do

1 True freedom of contract when establishing labour relations is, essentially, very difficult to accomplish. It is particularly difficult in countries with a high rate of unemployment. 
not necessarily represent wellbeing for the majority of the population, although they are presented even today as a formula for broad social prosperity. The truth is, in fact, that for economic growth to have social meaning and justification everyone must benefit from it, the workplace alone has small significance if work in it is not done in conditions befitting of man and if it does not provide a satisfactory income.

Considering the ever growing number of workers, legal regulation of labour relations becomes a prioritised interest for employers. Labour relations were arranged on a purely individual basis, on the principle of the autonomy of will, so that in the legal system of the 19th century the employment contract was not only a purely obligational relation, but also a purely private-law relation. Thusly normed, it was in open conflict with reality because it was set up on an individualist basis from the very beginning (Živković, 1940:105-106). The workpeople had little of the proclaimed freedom and equality, considering they fell from medieval personal dependence to a pronounced economic dependence, in many ways more difficult and dangerous than the medieval. The individualist legal system served only the employers' most egotistic interests (Živković, 1940: 107).

The liberal order enabled exceptional industrial development during the 19th century. Conversely, it had fatal consequences for the workers, who were abandoned by nearly every form of protection. The order upheld exclusively the employers' interests and had neither the sense nor the will for a social approach to the working class (Ravnić, 2004: 351). Faced with the difficult condition of the workers, the state commences with the legal ordering of labour relations, primarily in the area pertaining to basic working conditions. The first legislation of this type is passed in England in 1802 (Ravnić, 2004:340). Of course, it is a separate question whether the states of that time embraced interventionism in the domain of labour spurred by the altruism of the ruling structures or by the fear for their status amid the growing dissatisfaction of the populace. The events of the 19th and early 20th century point in favour of the latter reason. Moreover, the formation of the International Labour Organisation itself and the attempt to regulate labour relations on an international level came about, for the most part, from the fear of the October Revolution "spilling over" into western countries. ${ }^{2}$

The workers' movements themselves had strong international influence, especially when they included a political component. The Communist Manifesto of 1848 called all the workers of the world to unite. Great influence was achieved

2 The victory of the October Revolution had a great influence on the workers movement in western countries, to such an extent that it spawned a revolutionary situation in Europe. The statement of the Prime Minister of the British government, Lloyd George, on the eve of the peace conference is frequently cited in connection to this, it reads: "Let us hurry with the reforms because the revolution knocks at our door too". (Šunderić, 2001: 48). 
by Karl Marx, as well as the First (1864) and Second International (1889) (Ware, Panikkar, Romein, 1960: 162-163). The unions were banding together on the basis of individual trades, and the main goal of that was notifying the members of trade disputes in various countries and to prevent workers in one country serving as strike-breakers in another (Ware, et al. 1969:163). Workers, to protect themselves from coarse exploitation, began organising and making demands which, fundamentally, boiled down to improvements in working and living conditions. Workers associations and taking collective action served precisely to achieve those goals (Ravnić, 2004: 350). Although the first attempts did not meet with a welcoming response, by the late 19th century pressures aimed at legally guaranteeing workers' rights mount (Servais, 2005:22).

The question of the workers was a subject of the Roman Catholic Church's interest too, from the very emergence of capitalism and constituting of the working class (Maštruko, 1981:11). Besides that, the second half of the 19th century was marked by a long process of interaction between the traditional Roman Catholic orthodoxy and various forms of contemporary European life. One of them was the question of social justice in an industrial society, which is the subject of Rerum novarum (Ling, 1993:411-412).

\section{Pope Leo XIII}

Pope Leo XIII was the head of the Roman Catholic Church from the 20th of February, 1878, to the 20th of July, 1903. He was born Gioacchino V. Pecci in Carpineto, Italy, on the 2nd of March, 1810. (Crowell-Collier, 1971:502). Even as a boy he was described as an exceptional personality. He showed early interest in the Latin language, which he retained throughout his life (Kelly, 1996:311). He studied in Viterbo (1818-1824), at Collegium Romanum (1824-1832), as well as at the Academy of Noble Ecclesiastics ${ }^{3}$, in the period from 1832 to 1837. He was ordained priest in 1837 and appointed Nuncio to Brussels in 1843. From there he travelled the neighbouring countries taking interest in problems that existed at the time. He was elevated to the College of Cardinals in 1853 and elected to the papacy in 1878 (Crowell-Collier, 1971:502). During his visit to Paris, London, and other cities he made first contacts with the industrialized, parliamentary Europe. In Vatican he encouraged the study of astronomy and natural sciences, calling the catholic historians to unbiased writing. He opened the Vatican archives (1883) to scientists, regardless of their faith (Kelly, 1996:311). He maintained friendly relations with England, Russia, and Japan. He helped churches in South and North America and established a permanent Apostolic Delegation to Washington (1893) (Crowell-Collier, 1971:503).

3 Now: Pontifical Ecclesiastical Academy 
The basic intention of Pope Leo XIII and his particular contribution was the harmonisation of the church with the circumstances of that age and the opening of the dialogue between the church and the society. He did that, in particular, through a series of announcements (Kelly, 1996:311). With that goal, his instructions addressed the most significant questions about family, freedom, socialism, the relations between workers and employers, the just use of political power, the threat of secret societies, the duties of Christians, and the constitutions of Christian states (Wine, 2012: 5). By way of numerous encyclicals, he expressed his stance on the most important social questions of that age. Thus, in the encyclical Quod apostolici muneris (1878) he expressed his opposition to socialism, communism, and nihilism. He expressed his stance against Freemasonry in the encyclical Humanum genus (1884) and on marriage in Arcanum illud (1880), etc. (Kelly, 1996:311). Several encyclicals of Pope Leo XIII, such as Immortale Dei (1885), Diuturnum illud (1881), Libertas praestantissium (1888), were dedicated to the socio-political order (Kelly, 1996:311).

\section{Contents of the encyclical}

As we have already mentioned, the encyclical Rerum novarum was issued on the 15th of May, 1891, ${ }^{4}$ and in literal translation from Latin means: Of new things. The reason for its issuing is mentioned in the introductory part. It is the "workers' question", more specifically, the condition of the working classes due to vast advances in industrial pursuits and science; the changed relations between masters and workmen; the accumulation of wealth in the hands of the few and the poverty of the vast majority; the increased self-awareness of the workers and their need for connectedness. The letter is an attempt to refute false teaching, as was done on former occasions for other like matters. It is stated that the condition of the workers is particularly worsened by the abolition of workingmen's guilds (and no other organization founded to replace them), hence they have been left to themselves and to the inhumanity of employers. The mischief, it is further explained, has been increased by rapacious usurers who were more than once explicitly condemned by the Church.

Immediately afterwards, he condemns socialism as a solution to the workers' problems. Socialists, Pope Leo XIII thought, stirred up the poor man's envy of the rich. They wrongly contend that the present mischievous state of things will be set to rights by doing away with private property and replacing it with the common property of all, for which they advocate. On the contrary, the encyclical

4 The text of the encyclical is quoted from the book The Great Encyclical Letters of Pope Leo XIII. The original edition of the book was published in 1903 by Benziger Brothers, New York, Cincinnati, Chicago. Based on it, a facsimile edition was published in 2012 by the publisher Forgotten Books, San Bernardino. 
asserts that this theory is not only clearly powerless to end the controversy, but that the working men themselves would be among the first to suffer. Namely, by transforming private into common property, the socialists are worsening the condition of the workers because they deprive them of the liberty of investing their wages, and in that way prevent them from increasing their families' estates and wealth.

In a further defence of private property, it is stated that every man has by nature the right to possess property and that this is, in fact, one of the chief points of distinction between man and "the animal creation". Considering it is a most sacred law of nature that a father should provide for the life and education of those whom he has begotten, it is natural that his children should be by him provided with all that is needful to enable them to keep themselves decently from every misfortune. That duty can be fulfilled only by the ownership of productive property, which will be transmitted to his children by inheritance. Therefore, the abolition of private property would, besides injustice, create upset and disturbance in all classes considering the door would be thrown open to envy, to mutual invective, and to discord; the private incentive for exerting the talents and industry of the individual would disappear. That way the sources of wealth themselves would run dry too.

Instead "true remedies", i.e. solutions, are offered in the encyclical. First of all, it is stated that the subject is a problem which cannot be solved apart from the intervention of religion and of the Church, and that all the striving of men will be in vain if they leave out the Church. For the avoidance of doubt, it is further recognised that it is impossible to remove inequality from civil society considering all people differ in mental capacity, diligence, health, and strength. The intent of socialists to achieve equality among men is in vain because it is striving against nature. Considering the wealthy and working classes need each other unconditionally it is necessary to create agreement between them. Reconciliation and unity between the wealthy and the workers is possible to achieve by reminding each of their duties to the other, and especially those springing forth from justice. The encyclical prescribes the fundamental duties of the workers and the fundamental duties of the wealthy. The fundamental duties of the workers are: never to injure the property, nor to outrage the person, of an employer; never to resort to violence in defending their own cause, nor to engage in riot or disorder; and, finally, to have nothing to do with men of evil principles who cleverly excite foolish hopes and overpromise. The fundamental duties of the wealthy owner and the master: not to treat their workers as their slaves; to respect their dignity as human beings; not to misuse men as though they were things in the pursuit of gain, or to value them solely for the worth of their physical powers; to keep in mind the workers' religion and the good of their souls 
and to see that the workers have time for their religious duties; to not expose the workers to corrupting influences and incitements to sin and not lead them away to neglect their homes and families, or to squander their earnings; to never tax their workers beyond their strength, or employ them in work unsuited to their sex and age.

The greatest duty of the employer is to give everyone what is just, i.e. to determine the wage to a just measure, which depends on many circumstances. If a workman's wages be sufficient to enable him comfortably to support himself and his family, he will find it easy, if he be a sensible man, to practice thrift. That way he will achieve that to which nature itself would urge him, which is to, by settling expenses, secure modest assets.

In order to achieve agreement and better relations between the social classes, the encyclical calls for, in accordance to the Church's teachings, a distribution of the wealth with others, i.e. for helping the indigent, however, not in a pursuit of justice but "of Christian charity, the fulfilment of which cannot be sought in human law". On the other hand, it is also emphasized that poverty is no disgrace, that there is nothing to be ashamed of in earning their bread by labour, as well as that all that can be resolved through Christian brotherhood. Specific measures that the prelates should undertake boil down to spreading Christian teaching and the renovation of society on its foundations.

Besides the Church, the state plays a crucial role as well, particularly through intervention in disputes between the workers and the employers. The state must protect all citizens because "the landless workers are citizens by nature the same as the rich" it would, therefore, be irrational to provide for one portion of the citizens and neglect another. Some areas in which the state must intervene in particular are pointed out. They are: the safeguarding of private property, the defence of labour, and the education for thrift.

Explaining the section on the defence of labour, Pope Leo XIII points out that excessively long hard labour and insufficient wages are frequently the cause for workers voluntarily ceasing work so it is most helpful if the authorities, through the application of law, forestall and prevent evil from flaring up by removing the causes and reasons. However, the Pope is explicitly against strikes because such work stoppages are injurious not only for the employers and workers alike, but to trade and to the general interests of the public as well; moreover, they are customarily not without violence and disorder. Additionally, the right to strike, today considered the fundamental social right of the workers and their organisations (Lubarda, 2012:979), had a long developmental path and it was very difficult to achieve. The sensitivity of that question is best illustrated by the fact that not one convention or recommendation of the International Labour 
Organisation contains special clauses on the recognition of the right to strike (Šunderić, 2001: 203), instead it had to be examined in the context of the freedom of association (Betten, 1993: 67). Interpreting the provision of article 3 of International Labour Organisation Convention No. 87 on Freedom of Association and Protection of the Right to Organise (1948) ${ }^{5}$ the Committee on Freedom of Association concluded that the trade union freedoms include also the right to strike (Betten, 1993:67).

In reference to the working conditions, it is emphasized that they must be such that no man may with impunity outrage the human dignity. For the duration of holy days, the work should cease and the workers be saved from their dependence on men of greed who maliciously and immoderately use human beings and things for personal gain. So much labour should not be demanded that from excessive exertion the spirit wanes and the body succumbs to exhaustion. Care should be taken that daily labour is not protracted over longer hours than strength admits. Work which is suitable for a strong and grown man cannot rightly be required from a woman or a child and in regard to children, care should be taken not to let them enter workshops until their bodies, minds, and spirits are sufficiently developed.

The right to association, including establishing workers' and employers' associations, the Pope considers a natural right of man. Therefore, it is not the office of the state to forbid their existence, but to assist in the realization of the right to association. Workers' associations should be so organised and governed as to furnish the best and most suitable means for attaining the proposed purpose, which consists of enabling each individual member to derive utmost benefits for the body, soul, and family.

Near the very end of the encyclical, it is emphasised that it is important for the state that the ongoing fight for the condition of the workers is led with determination and astuteness. Therefore, Christian workers are called to be connected by associations and, if they have wise leaders, follow on the path which was trodden by their fathers and ancestors before them with so much advantage to themselves and the common weal.

In the end, Pope Leo XIII concludes that hands should be put to work straightway, lest the evil become even greater, clearly aware of the gravity of the moment. To that end, state authorities should avail themselves of the laws and regulations, and the employers and workers should be mindful of their duties.

5 "Official Journal of the Federative People's Republic of Yugoslavia-International agreements", no. 8/58. Article 3 determined the right of workers' and employers' organisations to, among other things, organise their administration and activities and to formulate their action programmes. The public authorities must, on the other hand, refrain from any interference which would restrict this right or impede the lawful exercise thereof. 


\section{The significance and influence of the Rerum novarum encyclical}

Although Rerum novarum was not the first social encyclical, considering that Pope Benedict XIV issued Vix pervenit (mentioning the disappearance of feudalism and the birth of capitalism) in 1745, from the time of Pope Leo XIII and his encyclicals, of which Rerum novarum (and, to a certain degree, Libertas) particularly stand out, the high clergymen of the Roman Catholic Church reject economic liberalism and the conception of natural order in economic and social relations (Maštruko, 1981: 14, 29). Instead, they begin to advocate, under the direct influence of the Pope, for a theological understanding of the ideas of natural order in which the concept of "the natural" represents a special human nature, created by God Himself (Maštruko, 1981:14).

The Catholic ideology of social liberation received its final shape with the Rerum novarum encyclical, and on significant anniversaries 1931, 1981, and 1991 it was expanded through new encyclicals and in part brought into accord with the new times (Ekmečić, 2011:296). On the fortieth anniversary of the encyclical's issuing (1931), Pope Pius XI (1922-1939) issues the Quadragesimo anno encyclical which, already in its title, refers to Rerum novarum and, among other things, treats the problem of the relations of labour and capital. Underscoring the assertion of Leo XIII about the interdependence of labour and capital, Pius XI calls for establishing a balance between them, which will most easily be accomplished through just remuneration for work (Maštruko, 1981:42).

Rerum novarum also exerted, among other things, influence on labour law. Its development progressed in close correlation with the value postulates of protestant teaching on labour, utopian socialism, philanthropic employers, Marxist philosophy but also social Catholicism, beginning with the Rerum novarum encyclical (Lubarda, 2012:160). Although it was noted that the right for social safety demanded in the encyclicals boils down to "the right to sacrifice other people's things in a state of emergency", i.e. that in the encyclicals there is no mention of any social right in a technical legal sense in which the state would be the obligor and that those moral obligations were used to "manoeuvre around the demands of the working class and unprovided for persons generally" (Stupar, 1963: 77), that does not diminish the importance of the Rerum novarum encyclical and its positive influence on the improvement of the condition of workers and the development of the system of social safety. Among other things, the issuing of this encyclical incited the formation of national Christian labour unions. In 1908 in Zurich they founded the International Secretariat of Christian Trade Unions, becoming open to the reception of Catholic as well as protestant trade unions (Ware et al. 1960:163). The encyclical is also described as a "lesson on saving the modern, industrial society" by introducing the social security of the 
worker, the organisation of labour and the whole social life, and it represented what "The Communist Manifesto" was for the communists, but it is also considered that such "social Catholicism" gave birth to the modern fascism of all stripes (Ekmečić, 2011: 359-360).

The Rerum novarum encyclical is also significant because it has, in several places, embodied important principles which were clearly expressed 57 years later, in the text of the International Labour Organisation Convention No. 87 on the Freedom of Association and Protection of the Right to Organise. It is considered that it had a "galvanizing" influence on thinking worldwide and that it was followed by a torrent of activities within the Roman Catholic Church in that regard, from which sprang dynamic movements with the goal of founding (Roman Catholic) Christian trade unions (Duning, 1998:151).

\section{Concluding remarks}

Rerum novarum was a product of its time. The conditions of the society in that age necessarily imposed the adoption of the appropriate stance on all significant social factors. One of them was the ever more numerous workers and their organisations (trade unions). Due to the exceptionally unfavourable material and legal status, their dissatisfaction was becoming ever greater and more pronounced so that they relatively quickly became a factor which was impossible to ignore. Specific measures with the goal of improving the condition of the workers were also proposed by the Roman Catholic Church, and Pope Leo XIII's encyclical Rerum novarum was undoubtedly the most impressive. Regardless of the circumstances and reasons for its issuing, as well as the twisted interpretations (which are a frequent companion of great ideas), Rerum novarum had a strong response throughout the world and was a motivation for numerous other efforts to improve the condition of the workers.

\section{Bibliography}

Бајич, С. (1937), Основи радног права-општи део (The fundamentals of labour law-general part), Издавачко и књижарско предузеће Геца Кон, А.Д. Београд Betten, L. (1993), International Labour Law, Kluwer, Deventer, Boston

Crowell-Collier. (1971). Collier's Encyclopaedia, 1971, Volume 14, Crowell-Collier Educational Corporation, 1971

Duning, H. (1998), The origins of Convention No. 87 on the Freedom of Association and Protection of the Right to Organise, International Labour Review, Vol. 137, No. 2 
Ling, Т. (1993), Историја религије истока и запада (The history of religion of the East and the West), Српска књижевна задруга, Београд

Екмечић, М (2011), Дуго кретање између клања и орања. Историја Срба у новом веку (1492-1992), (The long voyage between slaughter and ploughing. The history of Serbs in the new era (1492-1992), Evro Giunti, Београд

Живковић, Р. (1940), Проблем правне природе уговора о раду (у светлости историје и савременог друштвеног и привредног поретка), докторска дисертација (The problem of the legal nature of the employment contract (in light of the history and contemporary societal and economic order), doctoral dissertation); Правни факултет Универзитета у Београду

Kelly, J.N.D. (1996). Oxford Dictionary of Popes, Oxford University Press

Maštruko, I. (1981), Klasni mir katoličanstva (The class peace of Catholicism), Marksistički centar, Logos, Split

Ravnić, A. (2004), Osnove radnog prava-domaćeg, usporednog i međunarodnog (The fundamentals of labour law: domestic, comparative, and international), Pravni fakultet u Zagrebu, Zagreb

Servais, J.M. (2005), International Labour Law, Kluwer Law International, The Hague

Tintić, N. (1969). Radno i socijalno pravo, knjiga prva: radni odnosi (I), (Labour and social law, book one: labour relations (I), Pravni fakultet u Zagrebu, Zagreb

Ware, C. F., Panikkar, K.M., Romein, J.M., (1969), Historija čovječanstva-kulturni i naučni razvoj, treći i četvrti dio), (The history of humanity-cultural and scientific development, $3^{\text {rd }}$ and $4^{\text {th }}$ volume), Naprijed, Zagreb

Wine, J.J. (2012), The Great Encyclical Letters of Pope Leo XIII, Forgotten Books

Шундерић, Б. (2001), Право Међународне организације рада (The law of the International Labour Organisation), Правни факултет у Београду

Translated by: Suzana Ilijev 


\section{Др Горан Обрадовић, \\ Ванредни професор Правног факултета, \\ Универзитет у Нишу}

\section{RERUM NOVARUM ПАПЕ ЛАВА ХIII}

\section{Резиме}

Крај ХІХ и почетак ХХ века обележио је велики напредаку производњи, који је великим делом био последица бројних открића до којих се убрзано долазило. Положај радника није пратио тај напредак, већ су они били његове жртве. Све веће друштвено богатство гомилало се у рукама малог броја људи, док је огромна већина радника била на самом рубу физичког опстанка. Све чешће и све израженије незадовољсто утицали су да државе и важни друштвени чиниоци заузму став о положају радника и предузму мере зарад његовог побољшања. У том правиу, свестан крајње неповољног положаја радника, али и опасности од социјализма и комунизма, деловао је и папа Лав XIII, нарочито својом енцикликом Rerum поvarum. У раду се прави осврт на положај радника у време доношења енциклике, анализира њен садржај, а у једном делу разматра и значај енциклике и њен утицај на даљи развој права радника.

Кључне речи: Rerum novarum, рад, радници, штрајк. 